\title{
Anti-immigration Policies and Fear of Deportation: A Human Rights Issue
}

\author{
David Becerra ${ }^{1}$ (D)
}

Published online: 17 August 2016

(C) Springer International Publishing 2016

\begin{abstract}
This paper examines how recent immigration policies and immigration enforcement strategies have impacted Latino immigrants in Arizona. Data were drawn from a sample of adult Latino immigrants $(n=213)$ living in Arizona. Analyses examined the relationship between fear of deportation and the impact of immigration policies on various aspects of daily life of Latino immigrants as a result of US immigration policies. Results indicate that participants who reported a greater fear of deportation were also significantly more likely to report: (1) trouble keeping a job; (2) trouble finding a job; (3) having been asked for immigration documents; (3) that friends have suffered; (4) that their family has suffered; (5) lower confidence that police will treat Latino immigrants fairly; (6) lower confidence that the courts will treat Latino immigrants fairly; and (7) lower confidence that they will have a better future. Implications for social work practice, advocacy, and research are discussed.
\end{abstract}

Keywords Immigration - Latinos · Human rights · Immigration policy $\cdot$ Fear of deportation

\section{Introduction}

During the Obama Administration, a record number of immigrants have been deported (Gonzalez-Barrera and Krogstad 2014). In addition to the increase in immigration enforcement strategies at the federal level, which include apprehension, deten-

David Becerra

David.Becerra@asu.edu

School of Social Work, Arizona State University, Phoenix, AZ 84004-0689, USA tion, and deportation, several states have implemented restrictive immigration policies aimed at negatively impacting undocumented immigrants. The combination of immigration policies and enforcement strategies at the federal, state, and local levels, and their deleterious consequences, has created a climate of fear among undocumented immigrant populations in the United States (US).

According to Article 13 of the Universal Declaration of Human Rights, all individuals have the right to freedom of movement (United Nations 1948). The increase in world migration over the past 25 years led to the adoption of the International Convention on the Protection of the Rights of All Migrant Workers and Members of Their Families, which highlights the fact that migrants are human beings with children and families, and not simply workers. In addition, the convention focuses on the human rights violations that migrants and their families endure (United Nations 1990). Unfortunately, the US is currently not a party to this convention, which allows for the US to continue to implement harsh and restrictive immigration policies that negatively affect undocumented immigrants and their families. Nevertheless, social workers in the US are ethically obligated to fight against harmful policies and advocate on behalf of migrants and their families. In order to accomplish this, social workers must understand how these policies and the fear of deportation they produce negatively impact undocumented immigrants in the US. The purpose of this study is to contribute to the understanding of the impact of current immigration policies and enforcement strategies on the lives of Latino immigrants in the US.

\section{Current Harmful Immigration Policies}

Since the last wave of anti-immigrant sentiment in the mid1990s, numerous anti-immigrant policies have been passed at 
the federal and state level. These policies have had an impact on local law enforcement agencies who often are used to enforce federal and state immigration policies. In 1994, California passed Proposition 187 which barred undocumented immigrants from receiving non-emergency health care, public social services, and public education (Valentino, Brader, and Jardina 2013). In 1996, Congress passed the Personal Responsibility and Work Opportunity Reconciliation Act (PRWORA) which specifically prohibited undocumented immigrants' access to public services (PRWORA; U.S. Public Law 104-193). Despite much public backlash regarding Prop 187 and PRWORA, these policies helped set the stage for more recent anti-immigration policies which negatively affect a new generation of Latino immigrants in the US.

Arizona has been at the forefront of the most recent statelevel anti-immigration policies and policies targeted specifically at the Latino population within the state. There are over six million people living in Arizona, of which slightly over two million are Latinos. Maricopa County is the most populous county, which includes over four million residents, including 1.2 million Latinos (US Census Bureau 2015). In 2000, Arizona passed Proposition 203 which eliminated bilingual education and segregates mostly Latino students who are classified as English Language Learners (Combs et al. 2005). In 2004, Arizona passed Proposition 200 which requires identification and proof of immigration status when applying for public benefits. In addition, Prop 200 mandates state employees report anyone they suspect to be undocumented to immigration officials under the threat of a misdemeanor charge for failing to comply with the law (Furman, Langer, Sanchez, and Negi 2007). In 2006, Arizona passed Proposition 300 which prohibits all university students who are not US citizens or permanent residents from receiving financial aid and requires them to pay out-of-state-tuition (Aguirre 2012).

Espousing anti-immigrant positions has been politically advantageous for state and local politicians in Arizona. As a result, policies that further restrict undocumented immigrants' ability to work and live without fear continue to be implemented. In 2007, the Legal Arizona Workers Act (LAWA) was passed, which requires employers to use E-Verify to validate the immigration status of new employees. Under LAWA, the state can also suspend or revoke business licenses for knowingly hiring an undocumented worker. Although the bill was touted as a way to crack down on businesses that knowingly hire undocumented workers, through 2012, only one business had lost its license as a result of hiring undocumented workers (Ayón et al. 2012). Instead of targeting businesses, the bill forced undocumented immigrants further into an underground economy. Businesses have used LAWA and the threat of detection and deportation to exploit undocumented workers by forcing extra working hours, withholding earned wages, and reducing hourly wages (Ayón et al. 2012).

The most controversial immigration policy to come out of Arizona recently was Arizona Senate Bill 1070 that was enacted in 2010 (SB1070). Although federal law already required immigrants, including legal permanent residents, to carry immigration documents at all times, SB1070 allowed state and local law enforcement officers to consider race, color, or national origin to request proof of immigration status from individuals they suspected may be undocumented (Pew Hispanic Center 2010). Although the US Supreme Court struck down three of the major provisions of SB1070 in 2012, the Supreme Court let stand the "show me your papers" requirement allowing law enforcement officers to continue to question an individual's immigration status (National Conference of State Legislatures 2012). Arizona's SB1070 was viewed as so restrictive that it was condemned by UN experts working under the mandate of the Human Rights Council and helped to increase the perception among Latinos and the general US population that Latinos were the most discriminated group in the US (Pew Hispanic Center 2010; United Nations Office of the High Commissioner for Human Rights 2010).

\section{Immigration Enforcement}

Deportations have increased dramatically during the Obama Administration (Gonzalez-Barrera and Krogstad 2014). During the Obama Administration, over two million undocumented immigrants have been deported; more deportations than during any other presidential administration in the US history (Gonzalez-Barrera and Krogstad 2014). Recently, there has been an increase in the number of children migrating to the US without their parents and, as a result, the apprehensions and deportation of children has also increased. From October 2013 to September 2014, there were 68,541 children who were apprehended by immigration officials (Deckert 2016). Although President Obama has stated the focus of deportations is on criminals, the majority ( $56 \%$ ) of those who have been deported since 2009 are non-criminals (GonzalezBarrera and Krogstad 2014). Latino immigrants represent the vast majority of those arrested, detained, and deported by Immigration and Customs Enforcement (ICE) (Kohli, Markowitz, and Chavez 2011). The emphasis on deportations at the federal level has led to the involvement of state and local law enforcement officers in immigration enforcement. Under section $287(\mathrm{~g})$ of the 1996 Immigration and Nationality Act, state and local law enforcement officers can be given the authority to stop and request documentation from individuals as well as detain them for not having proper immigration documents until they can be turned over to federal authorities to commence the deportation process. 
In Arizona, county officials have increased immigration enforcement and have found new ways to prosecute undocumented immigrants. The Maricopa County Attorney began prosecuting undocumented immigrants under the Arizona statute A.R.S. §13-2319. Originally, this statute was intended to punish those who profit from human smuggling. However, in an attempt to further criminalize the lack of immigration documentation, the Maricopa County Attorney began prosecuting undocumented immigrants under A.R.S. §13-2319 for being part of a criminal conspiracy to smuggle themselves into the US (Campbell 2011). This interpretation of the statute created criminal charges for undocumented immigrants when, historically, not having the proper documentation to be in the US was treated as a civil violation (Androff et al. 2011). In addition, the Maricopa County Sheriff's Office increased its attention on undocumented immigration and has been involved in numerous workplace and community raids which have caused fear to spread through Latino immigrant communities (Ayón and Becerra 2013). In 2013, the US Department of Justice indicted the Maricopa County Sheriff for using racial profiling to target Latinos in Arizona. However, the Sheriff continued his workplace and community raids even after he was ordered by the federal judge to cease his immigration enforcement tactics (Parvini 2015). The involvement of state and local law enforcement officers in stopping those they suspect of being undocumented workers, as well as their participation in workplace and community raids, leads to a lack of trust of law enforcement and the criminal justice system who are responsible for protecting members of the community (Messing, Becerra, Ward-Lasher, and Androff 2015).

\section{Fear of Deportation}

Previous studies have found that anti-immigration policies and the increase in immigration enforcement at the federal, state, and local levels have created fear, anxiety, and confusion within Latino communities (Arbona et al. 2010; Ayón and Becerra 2013). The fear of deportation has also been associated with negative social, emotional, and mental health outcomes such as social isolation, stress, anxiety, and depression (Arbona et al. 2010; Becerra et al. 2015; Capps et al. 2007; Finch and Vega 2003). In addition to the negative health implications caused by a continual fear of deportation, the escalation of workplace and community raids leaves undocumented immigrants more vulnerable to exploitation by their employers and to becoming victims of crimes.

As a result of the fear of detection and deportation, undocumented Latino immigrants have been found to be less likely to report abusive labor practices and exploitation from their employers (Brennan 2010; Cleaveland 2010). Employers are able use the fear of deportation to exert power over undocumented immigrants. For example, employers have been found to demand longer work hours, work with less or no pay from undocumented immigrants. In addition, undocumented Latinas face increased sexual harassment from employers or supervisors (Fussell 2011; Vellos 1996). Latino immigrants who fear deportation may also be less likely to notify law enforcement when they are victims of a crime (Reina, Lohman, and Maldonado 2014). The fear of deportation of themselves or of a loved one also puts Latinas at an increased risk of being abused by their partners (Messing et al. 2015; Reina et al. 2014). Previous studies have found that Latinas who fear deportation of themselves or their intimate partner are less likely to report being victims of a violent crime to the police (Menjivar and Bejarano 2004; Messing et al. 2015).

Given the extant literature, it was hypothesized that foreign born Latinos with a greater fear of deportation would report (1) more trouble finding a job; (2) more trouble keeping a job; (3) that their families have suffered; (4) that their friends have suffered; (5) less confidence that police officers will treat Latino immigrants fairly, (6) less confidence that the courts will treat Latino immigrants fairly; (7) less confidence that their family will have a better future; and (8) less confidence that their children will have a better future.

\section{Methodology}

After gaining approval from the institutional review board of the author's university, data for this study were collected in the summer and fall of 2014 from a sample of 213 adult Latino immigrant respondents living in Arizona (see Table 1). A nonprobability convenience sampling technique was used. Participants were recruited through social service agencies, churches, and faith-based organizations throughout Maricopa County, Arizona. Participants completed questionnaires in English or Spanish depending on the language preference of participants. Given the sensitive and vulnerable position of many of the participants, they were given an informed consent letter that did not require a signature, but explained the purpose of the study and the voluntary nature of participating. In addition, participants were verbally given the information regarding the purpose of the study and their rights as voluntary participants. In order to minimize the risks of participating in the study, no identifying information was collected. The questionnaire took approximately $15 \mathrm{~min}$ to complete.

\section{Sample}

The sample of 213 adult Latino immigrants included 72 $(33.8 \%)$ males and $141(66.2 \%)$ females. The mean age was 38 ; over $58 \%$ of the participants had less than a high school diploma/GED; and $53.1 \%$ reported their current 
Table 1 Descriptive statistics

\begin{tabular}{|c|c|c|}
\hline & $N$ & Percent $(\%)$ \\
\hline \multicolumn{3}{|l|}{ Age (years) } \\
\hline $18-25$ & 48 & 22.5 \\
\hline $26-30$ & 24 & 11.3 \\
\hline $31-35$ & 25 & 11.7 \\
\hline $36-45$ & 65 & 30.5 \\
\hline $46-55$ & 28 & 13.5 \\
\hline 56 and older & 23 & 10.5 \\
\hline \multicolumn{3}{|l|}{ Gender } \\
\hline Female & 141 & 66.2 \\
\hline Male & 72 & 33.8 \\
\hline \multicolumn{3}{|l|}{ Socioeconomic status } \\
\hline Very bad & 12 & 5.6 \\
\hline $\mathrm{Bad}$ & 47 & 22.1 \\
\hline Average & 113 & 53.1 \\
\hline Good & 36 & 16.9 \\
\hline Very good & 5 & 2.3 \\
\hline \multicolumn{3}{|l|}{ Education } \\
\hline None & 3 & 1.4 \\
\hline Some elementary school & 15 & 7.0 \\
\hline Elementary school & 24 & 11.3 \\
\hline Some middle school & 17 & 8.0 \\
\hline Middle school & 43 & 20.2 \\
\hline Some high school & 22 & 10.3 \\
\hline High school & 50 & 23.5 \\
\hline More than high school & 39 & 18.3 \\
\hline \multicolumn{3}{|l|}{ Years in the US } \\
\hline Less than 5 years & 11 & 5.2 \\
\hline $6-10$ & 22 & 10.3 \\
\hline $11-15$ & 59 & 27.7 \\
\hline $16-25$ & 93 & 43.7 \\
\hline More than 26 years & 28 & 13.1 \\
\hline
\end{tabular}

financial situation as “average." Participants' ages ranged from 18 to 87 years old with a mean of 17 years living in the US.

\section{Measures}

\section{Independent Variables}

The participants self-reported their gender, age, socioeconomic status, highest level of education, and years living in the US. Fear of deportation was a single item variable: "Regardless of your own immigration status, how much do you worry that you, a family member, or a close friend could be deported?" The response options were a Likert scale $(1=$ not much at all, $2=$ not much, $3=$ some, $4=$ a lot).

\section{Dependent Variables}

The participants were asked to respond to four statements regarding the impact of immigration policies on their lives. The statements they were asked to respond to were "As a result of the current immigration policies: (1) I have had more trouble finding a job; (2) I have had more trouble keeping a job; (3) My family has suffered; and (4) My friends have suffered." The response options were $1=$ strongly disagree to $5=$ strongly agree. In addition, the participants were asked to respond to four questions regarding the impact of immigration policies on their confidence in law enforcement, the criminal justice system, and their hope for a better future. The participants were asked to respond to the following questions: "As a result of the current immigration policies: (1) How much confidence do you have that police officers in your community will treat Latinos fairly?; (2) How much confidence do you have that the courts in your community will treat Latinos fairly?; (3) How much confidence do you have that your family will have a better future?; and (4) How much confidence do you have that your children will have a better future?" The response options were $1=$ very little to $4=$ a great deal.

\section{Analysis}

This study analyzed the relationship of participants' fear of deportation and the impact immigration policies have on their daily lives, as well as their confidence in law enforcement, the criminal justice system, and the hope for a better future. Specifically, eight sets of ordinary least squares (OLS) linear regression models were run to examine the relationship between the fear of deportation and (1) having trouble finding a job; (2) having trouble keeping a job; (3) suffering of the family; (4) suffering of friends; (5) confidence police officers will treat Latinos fairly; (6) confidence courts will treat Latinos fairly; (7) confidence their families will have a better future; and (8) confidence their children will have a better future. All models control for gender, age, socioeconomic status (SES), highest level of education, and years in the US.

As the data for this study were from a non-probability purposive sample, the data were not normally distributed. The dependent variables were skewed and did not meet the assumptions of a normal distribution for regression analyses. In order to address the issue of skewed data, a bias corrected and accelerated confidence interval (BCa) bootstrapping method was used (Efron and Tibshirani 1993). The bootstrap method does not need to meet the assumptions of normality because bootstrapping addresses the issue of a non-normal distribution by estimating the properties of the sampling distribution from the sample data (Field 2013; Rascati, Smith, and Neilands 2001). Multicollinearity tests were conducted 
(tolerance and VIF, results not shown), and the results indicated there were no issues with multicollinearity among the variables in the regression models.

\section{Results}

As seen in Table 2, model $1\left[\chi^{2}(6, n=207)=4.571, R=.454\right.$, $p<.001]$, the participants were asked to respond to the following statement: "As a result of the current immigration policies, I have had more trouble finding a job." The response options were $1=$ strongly disagree to $5=$ strongly agree. The results indicated a significant and negative relationship between higher levels of education and reporting trouble finding a job. In addition, participants with greater fear of deportation reported having greater trouble finding a job. In model 2 $\left[\chi^{2}(6, n=207)=4.471, R=.475, p<.001\right]$, the participants were asked to respond to the following statement: "As a result of the current immigration policies, I have had more trouble keeping a job." The results indicated a significant and negative relationship between a greater number of years living in the US and reporting more trouble keeping a job. In addition, the participants with greater fear of deportation reported having greater trouble keeping a job. In model $3\left[\chi^{2}(6, n=207)=\right.$ $3.273, R=.425, p<.05]$, the participants were asked to respond to the following statement: "As a result of the current immigration policies, my family has suffered." The results indicated a significant and negative relationship between a greater fear of deportation and participants reporting their families have suffered. In model $4\left[\chi^{2}(6, n=207)=2.517\right.$, $R=4.17, p<.05]$, the participants were asked to respond to the following statement: "As a result of the current immigration policies, my friends have suffered." The results indicated a significant and negative relationship between a greater fear of deportation and participants reporting that their friends have suffered.

As seen in Table 3, model $1\left[\chi^{2}(6, n=207)=6.197\right.$, $R=.243, p<.05]$, the participants were asked to respond to the following question: "As a result of the current immigration policies, how much confidence do you have that police officers in your community will treat Latinos fairly?" The response options were $1=$ very little to $4=$ a great deal. The results indicated a significant and positive relationship between a greater number of years living in the US and reporting greater confidence that the police will treat Latino immigrants fairly. In addition, participants with greater fear of deportation reported having significantly less confidence that the police will treat Latino immigrants fairly. In model $2\left[\chi^{2}(6, n=207)=3.381\right.$, $R=.329, p<.01]$, the participants were asked to respond to the following question: "As a result of the current immigration policies, how much confidence do you have that the courts in your community will treat Latinos fairly?" The results indicated a significant and negative relationship between a greater fear of deportation and confidence the courts will treat Latino immigrants fairly. In model $3\left[\chi^{2}(6, n=207)=1.469, R=.277, p<.05\right]$, the participants were asked to respond to the following question: "As a result of the current immigration policies, how much confidence do you have that your family will have a better future?" The results indicated that participants with a greater fear of deportation were significantly less likely to express confidence that their families will have better futures. In model $4\left[\chi^{2}(6, n=207)=1.672, R=.392\right.$, $p>.10]$, the participants were asked to respond to the following statement: "As a result of the current immigration policies, how much confidence do you have that your children will have a better future?" The results indicated no significant relationships.

Table 2 Impact of immigration policies on Latino immigrants

\begin{tabular}{|c|c|c|c|c|c|c|c|c|c|c|c|c|}
\hline \multirow[b]{3}{*}{ Gender } & \multicolumn{3}{|c|}{ Trouble finding a job } & \multicolumn{3}{|c|}{ Trouble keeping a job } & \multicolumn{3}{|c|}{ My family has suffered } & \multicolumn{3}{|c|}{ My friends have suffered } \\
\hline & \multirow{2}{*}{$\begin{array}{l}B \\
.065(.321)\end{array}$} & \multicolumn{2}{|c|}{$\mathrm{CI}(95 \%)^{\mathrm{a}}$} & \multirow{2}{*}{$\begin{array}{l}B \\
.262(.305)\end{array}$} & \multicolumn{2}{|c|}{ CI $(95 \%)^{\mathrm{a}}$} & \multirow{2}{*}{$\begin{array}{l}B \\
.166(.307)\end{array}$} & \multicolumn{2}{|c|}{$\mathrm{CI}(95 \%)^{\mathrm{a}}$} & \multirow{2}{*}{$\begin{array}{l}B \\
.262(.322)\end{array}$} & \multicolumn{2}{|c|}{ CI $(95 \%)^{\mathrm{a}}$} \\
\hline & & -.509 & .678 & & -.346 & .861 & & -.323 & .723 & & -.343 & .868 \\
\hline Age & $-.010(.017)$ & -.046 & .027 & $.012(.018)$ & -.028 & .050 & $-.017(.018)$ & -.038 & .006 & $-.006(.019)$ & -.043 & .037 \\
\hline SES & $-.015(.038)$ & -.080 & .053 & $.004(.037)$ & -.068 & .076 & $.001(.042)$ & -.084 & .084 & $.005(.040)$ & -.076 & .092 \\
\hline Education & $-.176^{*}(.083)$ & -.343 & .004 & $-.128(.091)$ & -.347 & .097 & $-.126(.087)$ & -.309 & .046 & $-.087(.090)$ & -.293 & .087 \\
\hline Year in US & $-.017(.018)$ & -.050 & .005 & $-.034 *(.016)$ & -.064 & -.011 & $-.017(.019)$ & -.048 & .008 & $-.028(.019)$ & -.060 & .004 \\
\hline Fear of Deportation & $.607 * * *(.153)$ & .256 & .853 & $.530 * *(.175)$ & .191 & .771 & $.470 * *(.176)$ & .134 & .776 & $.391 *(.195)$ & .002 & .781 \\
\hline$R^{2}$ & .216 & & & .233 & & & .169 & & & .163 & & \\
\hline
\end{tabular}

Standard errors in parenthesis. Gender $($ male $=0$, female $=1)$

$* p<.05, * * p<.01, * * * p<.001$

${ }^{\mathrm{a}} \mathrm{BCa}$ confidence intervals presented 
Table 3 The effect of immigration policies on Latino immigrants' perceptions of police, the courts, and the future

\begin{tabular}{|c|c|c|c|c|c|c|c|c|c|c|}
\hline \multirow[b]{3}{*}{ Gender } & \multicolumn{3}{|c|}{$\begin{array}{l}\text { Confidence police will treat } \\
\text { Latino immigrants fairly }\end{array}$} & \multicolumn{3}{|c|}{$\begin{array}{l}\text { Confidence courts will treat } \\
\text { Latino immigrants fairly }\end{array}$} & \multicolumn{2}{|c|}{$\begin{array}{l}\text { Confidence you will have a } \\
\text { better future }\end{array}$} & \multicolumn{2}{|c|}{$\begin{array}{l}\text { Confidence your children } \\
\text { will have a better future }\end{array}$} \\
\hline & \multirow{2}{*}{$\begin{array}{l}B \\
-.102(.126)\end{array}$} & \multicolumn{2}{|c|}{$\mathrm{CI}(95 \%)^{\mathrm{a}}$} & \multirow{2}{*}{$\begin{array}{l}B \\
-.058(.145)\end{array}$} & \multicolumn{2}{|c|}{$\mathrm{CI}(95 \%)^{\mathrm{a}}$} & \multirow{2}{*}{$\begin{array}{l}B \\
.024(.188)\end{array}$} & CI $(95 \%)^{\mathrm{a}}$ & \multirow{2}{*}{$\begin{array}{l}B \\
.090(.174)\end{array}$} & $\mathrm{CI}(95 \%)^{\mathrm{a}}$ \\
\hline & & -.353 & .149 & & -.347 & .231 & & $-.350 \quad .398$ & & $-.257 \quad .437$ \\
\hline Age & $-.011(.006)$ & -.023 & .001 & $.013(.007)$ & -.001 & .027 & $-.006(.009)$ & $\begin{array}{ll}-.024 & .021\end{array}$ & $-.013(.008)$ & $\begin{array}{ll}-.030 & .003\end{array}$ \\
\hline SES & $-.009(.016)$ & -.041 & .022 & $-.011(.018)$ & -.047 & .025 & $.032(.024)$ & $-.015 \quad .079$ & $.014(.022)$ & $\begin{array}{ll}-.029 & .058\end{array}$ \\
\hline Education & $-.029(.036)$ & -.101 & .043 & $.036(.042)$ & -.047 & .119 & $.044(.053)$ & $-.062 \quad .150$ & $.030(.050)$ & $-.069 \quad .130$ \\
\hline Year in US & $.019 * *(.008)$ & -.003 & .034 & $-.005(.009)$ & -.022 & .013 & $.010(.011)$ & $\begin{array}{ll}-.013 \quad .033\end{array}$ & $.002(.011)$ & $\begin{array}{ll}-.019 & .023\end{array}$ \\
\hline Fear of deportation & $-.103 * * *(.023)$ & -.118 & -.058 & $-.101 * * *(.026)$ & -.193 & -.068 & $-.312 *(.156)$ & $-.622-.004$ & $-.034(.020)$ & $-.073 \quad .005$ \\
\hline$R^{2}$ & .295 & & & .186 & & & .105 & & .102 & \\
\hline
\end{tabular}

Standard errors in parenthesis. Gender $($ male $=0$, female $=1)$

${ }^{*} p<.05,{ }^{* *} p<.01, * * * p<.001$

${ }^{\mathrm{a}} \mathrm{BCa}$ confidence intervals presented

\section{Discussion}

The results of this study indicated that Latino immigrants have been negatively impacted by recent immigration policies and enforcement strategies. Participants who reported a greater fear of deportation also reported greater difficulty finding a job and maintaining a job. These factors create additional stress for Latino families. Difficulty finding a job or keeping a job as the main income earner for the home puts the entire family at risk. These families may not have enough money to pay for necessities such as food, utilities, or rent. Undocumented immigrants in the US are not entitled to receive government assistance or participate in federal programs such as Supplemental Nutrition Assistance Program (SNAP) (formerly the food stamp program) or Temporary Assistance for Needy Families (TANF). As a result, undocumented Latino immigrants are at risk for not being able to provide the basic needs for their families, which can lead to deleterious health consequences for family members. Young children are especially vulnerable to the effects of poverty, and the lack of basic needs may lead to ongoing negative health consequences that continue in adulthood (Xue, Leventhal, Brooks-Gunn, and Earls 2005). The inability to find or maintain employment creates emotional and psychological stress for undocumented Latinos. Previous studies have found not being able to pay for utilities, buy a sufficient amount of food, pay for housing, as well as the familial tension that may ensue, as a result of unemployment, leads to stress, anxiety, and depression (McKee-Ryan, Song, Wanberg, and Kinicki 2005; Price, Choi, and Vinokur 2002). The stress, anxiety, and depression that accompany unemployment are of particular concern because those issues may go untreated as a result of undocumented immigrants being ineligible for federal public health insurance through Medicaid.
Participants with a greater fear of deportation indicated they have suffered, and their friends have suffered as a result of the recent immigration policies. Current immigration policies cause families to be separated and create numerous emotional concerns and long-term mental health issues. US immigration policies and enforcement strategies target undocumented immigrants; however, mixed-status families (where a US born child has one or both parents who are undocumented) also suffer (Mapp and Hornung 2016). US born children are US citizens and should be protected as such under US law. However, as Zayas and Bradlee (2014) argue, US immigration efforts to deport undocumented immigrants leaves undocumented parents facing deportation with the choice of either leaving their children in the US or taking them back to the parents' home country. In effect, this creates orphans in the US or US citizen exiles in a foreign country. Under current US immigration policies, the US government ignores the needs of US citizen children who are raised, schooled, and socialized in the US, and, in essence, those children lose their rights as US citizens and are forced to live in an unfamiliar country (Zayas 2015).

Workplace and community immigration raids also produce pervasive fear throughout Latino immigrant communities and negatively impact long-term psychological wellbeing, including families who did not have someone from their family detained (Ayón and Becerra 2013; Capps, Castañeda, Chaudry, and Santos 2007). Children are at greater risk because they see and experience the negative effects of the antiimmigration policies and enforcement strategies without understanding all of the factors that have created the hostile antiimmigrant climate, as well as not having the emotional capacity to process what they observe and experience.

Participants who had greater fears of deportation also reported lower confidence that police and the court system 
would treat Latino immigrants fairly. As a result of law enforcement officers being used to enforce immigration laws, Latino immigrants may feel like they are constant targets and that immigration enforcement takes precedence over the investigation of other crimes and enforcement of other laws. For example, over 400 reported sex crimes were not investigated by the Maricopa County Sheriff's Office in Arizona because that office instead focused on immigration and enforcement strategies that included community and workplace raids (Lacey 2011). Previous studies have found that Latinos perceive discrimination by the police (Becerra, Wagaman, Androff, Messing, and Castillo 2016). State, county, and local law enforcement being involved in the enforcement of immigration policies may exacerbate the often strained relationship between the police and Latino communities and lead to further mistrust of the police.

The results of this study also indicate that participants who fear deportation express lower confidence that the courts will treat Latino immigrants fairly. Immigrants in detention facilities are often subjected to human rights abuses such as physical and verbal abuse, lack of medical care, and inhumane conditions, which have led to over 100 deaths of immigrants in immigration detention since 2003 (Southwest Institute for Research on Women 2009; Granski et al. 2015; US Immigration and Customs Enforcment 2008). Once in detention, undocumented immigrants are often subjected to a process of mass hearings as part of Operation Streamline. In these hearings, immigrants are not given adequate legal counsel, they are questioned in groups of up to 80 people at a time, and they must answer all questions and enter their pleas in unison (Williams 2008). This policy creates an unjust situation for immigrants because they are deprived of due process and therefore may not understand their rights or the consequences of their pleas. Even children who are apprehended by ICE are subjected to human rights abuse as a result of their detention, emotional and physical abuse, denial of medical care, and lack of legal representation (Androff 2016). The abuses and inhumane conditions of detention facilities and the denial of due process in court proceedings contribute to perceptions that the courts will not treat Latino immigrants fairly.

Participants who reported a greater fear of deportation also reported less confidence that their own futures would be better than their current situations. Although, to date, there have not been any other Arizona state policies that have targeted undocumented immigrants to the level of Arizona's SB1070, Latino immigrants continue to fear deportation of themselves, their family members, or their friends because of the continuation of workplace and community raids, detentions, and deportations of undocumented immigrants. Latino immigrants are also aware of the anti-immigrant rhetoric coming from state and local politicians, as well as those running for president in 2016. The anti-immigrant rhetoric among politicians running for the highest office in the US has received national and international attention and contributes to a hostile environment for undocumented immigrants in the US.

Although the authority to enforce immigration policies rests at the federal level, some local officials continue to enforce policies in ways that ignore federal authority, promote fear among Latino immigrants, and create resentment toward law enforcement and the criminal justice system in the US. As mentioned previously, a federal judge found that the Sheriff of Maricopa County in Arizona violated the 4th Amendment (which guards against unreasonable search and seizure) and the 14th Amendment (which guarantees equal protection under the law) to the US Constitution, and used racial profiling in his immigration enforcement strategies. As a result, the Sheriff was cited by the judge for contempt of court (Parvini 2015).

The federal government has not provided clarity regarding immigration and the fate of undocumented immigrants in the US. President Obama has used executive orders to pass policies to help undocumented immigrants currently in the US such as the Deferred Action for Childhood Arrivals (DACA) and the Deferred Action for Parents of Americans (DAPA). However, President Obama has also deported a record number of immigrants, and he has recently ordered ICE to raid communities and to deport hundreds of Central American families who were part of a large wave of immigrants who crossed the border into the US in 2014 (Nakamura 2016; Pew Hispanic Center 2014). In addition, in 2016, the Supreme Court reviewed a challenge to the expansion of DACA and implementation of DAPA and issued a split 4-4 decision. Therefore, based on the lower court's ruling, DACA was not allowed to expand and DAPA was prohibited from being implemented. The mixed messages at the federal, state, and local levels create increased anxiety and confusion among undocumented immigrant populations in the US and may contribute to participants reporting less confidence they will have a better future.

\section{Limitations}

The cross-sectional data only provides a snapshot of respondents' perceptions of the impact of recent immigration policies on Latino immigrants. The sample size is small and not generalizable to the larger Latino immigrant population in Maricopa County, Arizona, or the US. The independent variable was a double-barreled question which may impact the interpretation of the results. Participants were recruited through social service agencies, churches, and faith-based organizations throughout Maricopa County. Latino immigrants who are not engaged with social service agencies, churches, or faith-based organizations, or who live in other regions of Arizona, may be impacted by recent immigration policies in different ways. Documentation status was not determined; therefore, comparisons between undocumented participants 
and those with legal status could not be ascertained. In order to reduce participant burden, the questions asked were not specific or numerous enough to examine issues faced by Latino immigrants in greater depth or detail. Also, some people may have refused to participate in the study for fear of their documentation status being reported. Despite these limitations, this is a difficult population to access and this study can guide future research and may provide potentially valuable information to social workers in communities with larger Latino immigrant populations.

\section{Implications}

\section{Implications for Social Work Practice and Education}

Social workers play an important role in supporting the needs of oppressed and vulnerable populations. Discrimination as well as prolonged stress and anxiety have been associated with serious negative physical and mental health implications (Araujo and Borrell 2006; Cavazos-Rehg, Zayas, and Spitznagel 2007; Gallo et al. 2011; Lassetter and Callister 2009; Williams and Mohammed 2009). In addition, previous studies have found that a significant number of immigrants experience traumatic events during the migration process (Potochnick and Perreira 2010) which leads to an increased risk for post-traumatic stress disorder (PTSD). Perreira and Ornelas (2013) found that among immigrants, $9 \%$ of adolescents and $21 \%$ of adults who experienced trauma were at risk for developing PTSD. It is therefore important that social workers in social service and community health agencies learn about the issues facing Latino immigrants. Social service agencies can begin to assess for stress, anxiety, depression, and PTSD that are the result of the documentation status, detention, deportation, familial separation, negative interactions with law enforcement and the criminal justice system, or the anti-immigrant political environment. This information can be used to develop culturally appropriate interventions to work with Latino immigrants and Latino immigrant communities.

Despite the growth of the Latino population over the past several decades, social work education programs have not adequately responded to the changing demographics. Schools of social work must do more to meet the needs of the growing Latino population. Social work education should incorporate effective and culturally appropriate interventions for working with Latino immigrants into social work curricula. Social work students should learn about the negative physical and mental health issues as a result of the migration process and how to assess for the stress, anxiety, depression, and PTSD caused by the migration process and current immigration policies and enforcement strategies. In addition, schools of social work do not produce the necessary Spanish-speaking social workers to meet the needs of the population (Vidal de Haymes and Kilty 2007), and field education offices often do not understand the additional pressures placed on bilingual social work students in field practicum placements (Engstrom et al. 2009). Therefore, schools of social work must place a greater emphasis on working with Latino immigrant populations.

As local law enforcement officers have become part of immigration enforcement strategies, social workers must work with law enforcement agencies, the criminal justice system, community-based organizations, and Latino communities to facilitate open communication and positive dialogue, interactions, and relationships. Social workers can help develop effective models that help create positive interactions between police officers and Latino communities. In addition, social workers can provide outreach and education to Latino immigrant communities to inform them about the legal rights for both documented and undocumented immigrants in the US (Becerra et al. 2012). Social workers must continue to advocate with, and on behalf of, Latino communities. Advocacy and education by social workers can help ensure the needs of immigrant families are being met, positive relationships with law enforcement agencies are developed, and harmful immigration policies are eliminated.

Due to US immigration policies that negatively impact mixed-status families, one or both parents may be detained and deported which often leads to the US-born child being placed with child protective services. Social workers' expertise in child welfare can provide leadership and guidance to child welfare and protection agencies in training agency directors, supervisors, and case managers and how best to work with undocumented children or US born children in mixedstatus families (Deckert 2016). Social workers can work with mixed-status families to develop a child custody and safety plan. Such a plan at minimum should include (1) a notarized plan for immediate childcare, (2) legal documents such as delegation of powers by parent, temporary guardianship for children, and power of attorney for the child, (3) emergency contacts in the US and country of origin, and (4) important documents such as birth certificates, social security cards, and shot records (Berger Cardoso, Faulkner, and Scott 2015, p. 9). In addition, social workers can partner with community-based organization to engage Latino immigrant communities to provide "Know Your Rights" education for immigrants when interacting with law enforcement and immigration officials such as those workshops organized by the American Civil Liberties Union (ACLU) and other community-based organizations (ACLU, n.d.). Social workers should also work with schools, the juvenile justice system, and child welfare or child protection agencies at the local and state levels to train them on the issues experienced by US-born children with undocumented parents so that the children can stay with a family member or close friend of the parents' choosing to minimize 
the negative effects of parent-child separation as a result of detention or deportation.

\section{Implications for Social Work Advocacy}

Although the US is not party to the International Convention on the Protection of the Rights of All Migrant Workers and Members of Their Families, the US is party to the UN Convention on the Elimination of all forms of Racial Discrimination (CERD) and the US government must report on its record to uphold the human rights protections within the treaty (US Human Rights Network 2016a). The Universal Periodic Review (UPR) is used by the UN Human Rights Council to enforce the protection of human rights. Through CERD and the UPR process, advocacy on behalf of immigrants has been conducted. CERD recently called for the rights of non-citizens in the US to be fully guaranteed and called for the end of Operation Streamline (CERD 2014). Social workers should participate in the UPR process by developing reports for review by CERD. UPR and the US Human Rights Network (USHRN) have templates on how to complete such reports, and social workers can work to complete them or assist NGOs in the completion of those reports (UPR, nd; USHRN 2016b). In addition, social workers must engage in advocacy at the local, state, and federal levels in order to pressure policy makers to adopt human rightsbased immigration policies (Libal and Harding 2015) that respect the needs and contributions of Latino immigrants and their families in the US.

Although much of the social work profession focuses on direct practice with individuals and families, social workers in the US are obligated to advocate for social justice by the National Association of Social Workers (NASW) Code of Ethics. NASW publicly supports comprehensive immigration reform and publishes materials on social work advocacy around immigration, but social workers can still do more to advocate on behalf of immigrant families and for changes to current US immigration policies. NASW should lead the way in social work advocacy efforts to change government policies and adopt more humane immigration policies. In addition, NASW should advocate to challenge government policies when they create ethical conflicts for social workers such as federal policies that prohibit services to be provided to undocumented immigrants or state and local policies that attempt to mandate social workers and other professionals report individuals who may be undocumented to immigration authorities.

\section{Implications for Future Research}

The results of this study can be used to guide future research examining the impact of the fear of deportation on the lives of Latino immigrants and their families. Future research could expand the scope of this study into longitudinal research to explore the long-term health, social, and economic impact of anti-immigration policies and enforcement strategies on the federal, state, and local levels. The current anti-immigrant political rhetoric of the 2016 presidential campaign should also be examined to determine the effect that anti-immigrant narratives have on Latino immigrants in the US. In addition, an analysis examining the impact of anti-immigration policies and enforcement in various regions across the US, including regions where no anti-immigration policies were passed at the state level, should be conducted. In order to examine relationships between the Latino immigrant community and law enforcement, future studies can examine not only Latino immigrants' perceptions of law enforcement, but also law enforcement officers' perceptions of Latino immigrant communities as well as law enforcement trainings, practices, or procedures that have been found to improve community relations. Future social work research should delve further into examining the emotional, mental health, and financial impact that immigration-related detentions and deportations have on Latino immigrant families and their children.

\section{Conclusion}

This study found that the recent immigration policies have led to a greater fear of deportation, which in turn is associated with greater negative outcomes for many Latino immigrants and less confidence in law enforcement and the criminal justice system. According to Article 13 of the Universal Declaration of Human Rights, all individuals have the right to freedom of movement (United Nations 1948). Unfortunately, in the US, despite being drawn to the country by US businesses that seek and employ undocumented immigrants, Latino undocumented immigrants and their children are subjected to discrimination and restrictive immigration policies and enforcement strategies that separate families and have long-lasting negative consequences. Social workers are obligated to promote social justice and social change with, or on behalf of, oppressed and vulnerable populations. Social workers need to make it necessary for elected officials to address the negative effects of the current anti-immigration policies and political rhetoric by educating the public and mobilizing communities to put pressure on their elected officials to act. Social workers must continue to demonstrate the negative impact these policies have on families in order to advocate for more humane immigration policies that value the contributions of undocumented immigrants.

Acknowledgments I would like to thank Sylicia McPhea for her assistance and her contribution to the preparation of this article. I would also like to express my sincere appreciation to all of the immigrant families who participated in this study. 


\section{References}

Aguirre, A. (2012). Arizona's SB1070, Latino immigrants and the framing of anti-immigrant policies. Latino Studies, 10, 385-394.

American Civil Liberties Union. (n.d.). Know your rights when encountering law enforcement. New York, NY. Retrieved from https://www.aclu.org/files/kyr/kyr_english.pdf

Androff, D. (2016). The human rights of unaccompanied minors in the USA from Central America. Journal of Human Rights and Social Work, 1(2), 71-77.

Androff, D., Ayón, D., Becerra, D., Gurrola, M., Moya-Salas, L., Krysik, J., Gerdes, K., \& Segal, E. (2011). U.S. immigration policy and immigrant children's well-being: the impact of policy shifts. Journal of Sociology \& Social Welfare, 38(1), 77-98.

Araujo, B., \& Borrell, L. N. (2006). Understanding the link between discrimination, mental health outcomes, and life chances among Latinos. Hispanic Journal of Behavioral Sciences, 28(2), 245-266.

Arbona, C., Olvera, N., Rodriguez, N., Hagan, J., Linares, A., \& Weisner, M. (2010). Acculturative stress among documented and undocumented Latino immigrants in the United States. Hispanic Journal of Behavioral Sciences, 32(3), 362-384.

Ayón, C., \& Becerra, D. (2013). Mexican immigrant families under siege: the impact of anti-immigrant policies, discrimination, and the economic crisis. Advances in Social Work, 14(1), 206-228.

Ayón, C., Gurrola, M., Moya-Salas, L., Androff, D., \& Krysik, J. (2012). Intended and unintended consequences of the employer sanction law on Latino families. Qualitative Social Work, 11(6), 587-603.

Becerra, D., Androff, D. K., Ayon, C., \& Castillo, J. T. (2012). Fear vs. facts: Examining the economic impact of undocumented immigrants in the US. Journal of Sociology \& Social Welfare, 39, 111-135.

Becerra, D., Quijano, L. M., Wagaman, M. A., Cimino, A. M., \& Blanchard, K. N. (2015). How immigration enforcement affects the lives of older Latinos in the U.S. Journal of Poverty, 19(4), $357-376$.

Becerra, D., Wagaman, M. A., Androff, D., Messing, J., \& Castillo, J. (2016). Policing immigrants: fear of deportation and perceptions of law enforcement and criminal justice. Journal of Social Work. doi: $10.1177 / 1468017316651995$.

Berger Cardoso, J., Faulkner, M., \& Scott, J. (2015). Parenting in the context of deportation. Houston \& Austin: University of Houston Graduate School of Social Work \& UT Child and Family Research Institute. Retrieved from http://sites.utexas.edu/cfri/files/2015/06 /Parenting-Deportation-Brief_Final.pdf.

Brennan, D. (2010). Thoughts on finding and assisting individuals in forced labor in the USA. Sexualities, 13(2), 139-152.

Campbell, K. M. (2011). The road to SB1070: how Arizona became ground zero for the immigrants' rights movement and the continuing struggle for Latino civil rights in America. Harvard Latino Law Review, 14, 1-21.

Capps, R., Castañeda, R. M., Chaudry, A., \& Santos, R. (2007). Paying the price: the impact of immigration raids on America's children. National Council of La Raza: The Urban Institute.

Cavazos-Rehg, P. A., Zayas, L. H., \& Spitznagel, E. L. (2007). Legal status, emotional well-being and subjective health status of Latino immigrants. Journal of the National Medical Association, 99(10), 1126-1131.

Cleaveland, C. (2010). "We are not criminals": social work advocacy and unauthorized migrants. Social Work, 55(1), 74-81.

Combs, M. C., Evans, C., Fletcher, T., Parra, E., \& Jiménez, A. (2005). Bilingualism for the children: implementing a dual-language program in an English-only state. Educational Policy, 19(5), 701-728.

Convention on the Elimination of all forms of Racial Discrimination. (2014). Concluding observations on the combined seventh to ninth periodic reports of the United States of America. New York: United
Nations. Retrieved from http://www.state. gov/documents/organization/235644.pdf.

Deckert, J. C. (2016). Social work, human rights, and the migration of Central American children. Journal of Ethnic \& Cultural Diversity in Social Work, 25(1), 20-35.

Efron, B., \& Tibshirani, R. (1993). An introduction to the bootstrap. New York: Capman \& Hall.

Engstrom, D. W., Min, J. W., \& Gamble, L. (2009). Field practicum experiences of bilingual social work students with limited English proficiency clients. Journal of Social Work Education, 45(2), 209224.

Field, A. (2013). Discovering statistics using IBM SPSS statistics (4th ed.). Los Angeles: Sage Publications.

Finch, B. K., \& Vega, W. A. (2003). Acculturation stress, social support, and self-rated health among Latinos in California. Journal of Immigrant Health, 5(3), 109-117.

Furman, R., Langer, C. L., Sanchez, T. W., \& Negi, N. J. (2007). A qualitative study of immigration policy and practice dilemmas for social work students. Journal of Social Work Education, 43(1), 133146.

Fussell, E. (2011). The deportation threat dynamic and victimization of Latino migrants: wage theft and robbery. The Sociological Quarterly, 52, 593-615.

Gallo, L. C., Jiménez, J. A., Shivpuri, S., Espinosa de los Moteros, K., \& Mills, P. (2011). Domains of chronic stress, lifestyle factors, and allostatic load in middle-aged Mexican-American women. Annals of Behavioral Medicine, 41, 21-31.

Gonzalez-Barrera, A., \& Krogstad, J. M. (2014). U.S. deportation of immigrants reach record high in 2013. Washington, D.C: Pew Research Center.

Granski, M., Keller, A., \& Venters, H. (2015). Death rates among detained immigrants in the United States. International Journal of Environmental Research and Public Health, 12(11), 14414-14419.

Kohli, A., Markowitz, P. L., \& Chavez, L. (2011). Secure communities by the numbers: an analysis of demographics and due process. Berkeley: The Chief Justice Earl Warren Institute on Law and Social Policy, University of California, Berkeley Law School.

Lacey, M. (2011). Arpaio is criticized over handling of sex-crimes cases. The New York Times. Retrieved from http://www.nytimes. com/2011/12/10/us/sheriff-joe-arpaio-criticized-over-handling-ofsex-crimescases.html

Lassetter, J. H., \& Callister, L. C. (2009). The impact of migration on the health of voluntary migrants in western societies. Journal of Transcultural Nursing, 20(1), 93-104.

Libal, K. R., \& Harding, S. (2015). Human rights-based community practice in the United States. New York: Springer.

Mapp, S., \& Hornung, E. (2016). Irregular immigration status impacts for children in the USA. Journal of Human Rights and Social Work, 1(2), 61-70.

McKee-Ryan, F. M., Song, Z., Wanberg, C. R., \& Kinicki, A. J. (2005). Psychological and physical well-being during unemployment: a meta-analytic study. Journal of Applied Psychology, 90(1), 53-76.

Menjivar, C., \& Bejarano, C. (2004). Latino immigrants' perceptions of crime and police authorities in the United States: a case study from the Phoenix metropolitan area. Ethnic and Racial Studies, 27, 120 148.

Messing, J. T., Becerra, D., Ward-Lasher, A. W., \& Androff, D. (2015). Latinas perceptions of law enforcement: fear of deportation, crime reporting, and trust in the system. Affilia, 30(3), 328-340.

Nakamura, D. (2016). Obama struggling with immigration rules and cruelties of deportation. The Washington Post. https://www. washingtonpost.com/politics/obama-struggling-with-immigrationrules-and-cruelties-of-deportation/2016/01/18/5c2d4258-bba7-11 e5-b682-4bb4dd403c7d_story.html

National Conference of State Legislatures. (2012). U.S. Supreme Court rules on Arizona's immigration enforcement law. Washington, D.C. 
Retrieved from http://www.ncsl.org/research/immigration/ussupreme-court-rules-on-arizona-immigration-laws.aspx

Parvini, S. (2015). Sheriff Arpaio admits to violating court order in profiling suit. Los Angeles Times. Retrieved from http://www.latimes. com/nation/la-na-arpaio-immigration-20150318-story.html

Perreira, K. M., \& Ornelas, I. (2013). Painful passages: traumatic experiences and post-traumatic stress among immigrant Latino adolescents and their primary caregivers. International Migration Review, 47(4), 976-1005.

Pew Hispanic Center. (2010). Hispanics and Arizona's new immigration law. Washington, D.C.: Pew Research Center.

Potochnick, S. R., \& Perreira, K. M. (2010). Depression and anxiety among first-generation immigrant Latino youth: key correlates and implications for future research. Journal of Nervous and Mental Disease, 198(7), 470-477.

Price, R. H., Choi, J. N., \& Vinokur, A. D. (2002). Links in the chain of adversity following job loss: how financial strain and loss of personal control lead to depression, impaired functioning, and poor health. Journal of Occupational Health Psychology, 7(4), 302-312.

Rascati, K. L., Smith, M. J., \& Neilands, T. (2001). Dealing with skewed data: an example using asthma related costs of Medicaid clients. Clinical Therapeutics: An International Peer Reviewed Journal of Drug therapy, 23(3), 481-498.

Reina, A. S., Lohman, B. J., \& Maldonado, M. M. (2014). "He said they'd deport me": factors influencing domestic violence helpseeking practices among Latina immigrants. Journal of Interpersonal Violence, 29, 593-615.

Southwest Institute for Research on Women. (2009). Unseen prisoners: a report on women in detention facilities in Arizona. Retrieved from http://sirow.arizona.edu/sites/sirow.arizona.edu/files/UnseenPrisoners. pdf

United Nations. (1948). The universal declaration of human rights. Retrieved from http://www.un.org/en/documents/udhr/history. shtml.

United Nations. (1990). International convention on the protection of the rights of all migrant workers and members of their families. Retrieved from http://www2.ohchr.org/english/law/cmw.htm.

United Nations Office of the High Commissioner for Human Rights. (2010). Arizona: UN experts warn against "a disturbing legal pattern hostile to ethnic minorities and immigrants". Geneva: OHCHR.
UPR. (n.d.) Documentation for NGOs. Geneva, Switzerland. Retrieved from http://www.upr-info.org/en/how-to/documentation-for-ngos

US Census Bureau. (2015). Quick facts: Arizona. Washington, DC: US Department of Commerce. Retrieved from http://www.census. gov/quickfacts/table/PST045215/04.

US Human Rights Network. (2016a). ICERD: The international convention to end all forms of racial discrimination. Atlanta, GA. Retrieved from http://www.ushrnetwork.org/icerd-project

US Human Rights Network. (2016b). 2015 CERD follow-up report template. Atlanta, GA. Retrieved from http://www.ushrnetwork. org/resources-media/2015-cerd-follow-report-template

US Immigration and Customs Enforcment. (2008). Fiscal year 2008 annual report. Retrieved from http://www.ice. gov/doclib/pi/reports/iceannual_report/pdf/ice08ar_final.pdf

Valentino, N. A., Brader, T., \& Jardina, A. E. (2013). Immigration opposition among US Whites: general ethnocentrism or media priming of attitudes about Latinos? Political Psychology, 34(2), 149-166.

Vellos, D. (1996). Immigrant Latina domestic workers and sexual harassment. American University Journal of Gender \& the Law, 5, 407432.

Vidal de Haymes, M., \& Kilty, K. M. (2007). Minority fellowship program Latino population grown, characteristics, and settlement trends: implications for social work education in a dynamic political climate. Journal of Social Work Education, 43(1), 101-116.

Williams, H. (2008). Statement to the US House of Representatives Subcommittee of Commercial and Administrative Law. Retrieved from http://judiciary.house.gov/

Williams, D. R., \& Mohammed, S. A. (2009). Discrimination and racial disparities in health: evidence and needed research. Journal or Behavioral Medicine, 32(1), 20-47.

Xue, Y., Leventhal, T., Brooks-Gunn, J., \& Earls, F. J. (2005). Neighborhood residence and mental health problems of 5- to 11year-olds. Archives of General Psychiatry, 62, 554-563.

Zayas, L. H. (2015). Forgotten citizens: deportation, children and the making of American exiles and orphans. New York: Oxford University Press.

Zayas, L. H., \& Bradlee, M. H. (2014). Exiling children, creating orphans: when immigration policies hurt children. Social Work, 59(2), 167-175. 